\title{
Miért is a gyermekek takarítanak a japán iskolákban?
}

\section{SOMODI JÚlia}

Károli Gáspár Református Egyetem, Bölcsészet- és Társadalomtudományi Kar, Keleti Nyelvek és Kultúrák Tanszék

Sokak által ismert tény, hogy a japán iskolákban a gyerekek takarítanak. Hogyan zajlik mindez a mindennapokban, hogyan készitik fel rá a gyerekeket, pedagógusokat, és mi lehet a pedagógiai célja ennek a tevékenységnek? Tanulmányomban bemutatom, hogy milyen társadalmi háttér rejlik egy olyan oktatási rendszer mögött, amelyben a nem akadémiai és az akadémiai iskolai tevékenységek azonos hangsúlyt kapnak, a takaritás megitélését tekintve hogyan osztályozzuk az egyes kultúrköröket, szó esik a japán nemzeti alaptantervröl, illetve arról, hogy konkrétan hogyan zajlik a takaritás a japán elemi iskolákban.

Kulcsszavak: Japán, iskolai rendszer, japán nemzeti alaptanterv, takaritás, ucsi-szoto, szenpai-kóhai

\section{Bevezetés}

Az iskolai takarítást megörökítő jelenetek ismerősek lehetnek szépirodalomból, képregényekből, de akár animékből is. Az alábbi idézet Nacume Szószeki 1906-ban íródott regényéből származik.

„Bár az óráimat már befejeztem, mégsem mehettem haza, mert még háromig ott kellett maradnom. Háromkor, így magyarázták el nekem, az ügyeletes tanulók jelenteni fogják, hogy az osztálytermeket kitakaritották, és nekem ellenöriznem kell az osztályok tisztaságát." (Nacume: A kölyök, 2002, 40. o. ford.: Vihar Judit).

A tanulmányhoz az adta az ihletet, hogy vannak olyan iskolai tevékenységek Japánban, amelyekre a japán iskolai oktatásban részesült magyarok és külföldiek követendő példaként tekintenek vissza. Ezek között említik a közös takarítást, projektmunkákat, iskolai tankertek gondozását, osztályok kétévenkénti újrasorsolását stb. (Pápai-Vonderviszt és Radnai, 1993). Mindezek olyan iskolai aktivitások, amelyek nem képezik szerves részét a tanórai oktatásnak, ám mégis kiemelten kezelik, céljuk pedig a szociális kompetenciák fejlesztése. A hazai szakirodalomban is gyakran említik, hogy a szociális készségek fejlesztésére nagyobb hangsúlyt kellene fektetni az iskolai oktatásban (Németh, 2008), így a japán példa mintaként szolgálhat. Mégis hogyan lehetséges, hogy a robotok hazájában, a világ gazdasági nagyhatalmai közé sorolt Japánban a gyerekek takarítanak az iskolában?

\section{Társadalmi háttér}

Hofstede (1980), holland kutató kulturális dimenziók alapján hasonítja össze az egyes kultúrákat. Az 1. ábrán japán és a magyar társadalom összehasonlítása látható. A kulturális dimenziók közül jelen tanulmány szempontjából az individualizmus-kollektivizmus kérdése mérvadó. Ez a kulturális dimenzió az egyik legmeghatározóbb az emberek viselkedését illetően. Míg a hofstede-i diagram szerint Japán individualizmus mutatója 46-os, addig Magyarországé 80. A szám a csoporton belüli függőségi fokot mutatja. Azokban a társadalmakban, ahol az individualizmus kap teret, az egyén szerepe kitüntetett, a társadalom pedig az egyén teljesítményét, az egyéni megmérettetést díjazza. Ezzel ellentétben, a kollektivista társadalmakban a "mi-tudat” erősebb az „éntudatnál”, és nem az egyének közötti versenyen van a hangsúly, sokkal fontosabb a tagok közötti együttmúködés (Hidasi, 1994. 40. o.). Japán köztudottan kollektivista társadalom, ahol 
fontos szerepe van a csoporthoz tartozásnak, a csoporton belüli harmóniának.

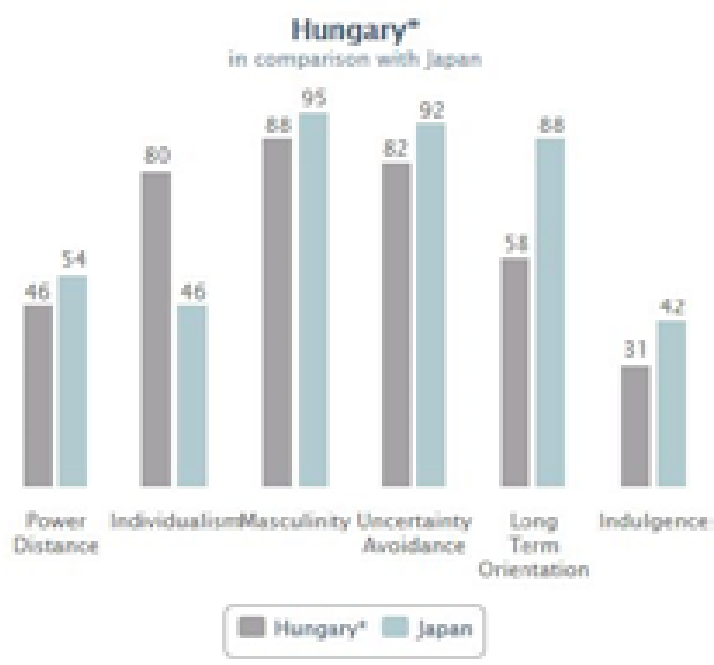

1. ábra. Hofstede-i dimenziók.

(forrás: https://geert-hofstede.com/hungary.html)

A csoporthoz való tartozás fontosságát mutatja az is, hogy egy japán bemutatkozáskor nem a státuszát vagy foglalkozását nevezi meg, hanem a céget, majd, az osztályt, részleget, amelyet képvisel. Például, XY vagyok az S cégtől (Chie, 1970. 3. o.; Hidasi, 1998. 140. o.). Ez a csoporttudat jelenti az intézmény erejét. Ennélfogva a csoportból való kirekesztést sokkal nehezebben élik meg a kollektivista társadalom tagjai, mint ott, ahol az én-tudat van előtérben.

Ugyancsak a csoporttudat fontosságát jelzi a japán ucsi-szoto viszony. Az ucsi jelenti a belső kört, akikkel egy csoportba tartozom: a család, az iskola, a cég. Ezzel szemben a szoto jelenti azoknak a körét, akik nem tartoznak a csoportunkhoz, akikhez nincs közöm, akik iránt nem tartozunk felelősséggel (Chie, 1970. 5. o.; Székács. 2003; Hidasi, 1998.).

Köztudott az is, hogy a japán társadalom hierarchikus felépítésü. Chie (1970) szerint a japán ember kapcsolatai három kategóriára bonhatók: szenpai (rangidős), kóhai (fiatalabb), dórjó (kolléga) (Chie, 1970. 26. o.). A gyerekek ezzel a hármas kapcsolatrendszerrel már az általános iskolában találkoznak: a szenpai, a felsőbb évfolyamra járó iskolatárs, akivel szemben a szóhasználat és megszólítás is más. A kóhai - értelemszerűen - a fiatalabb iskolatárs. A dórjó ez esetben az osztálytárs, később viszont a munkahelyi kollégák között ezen a szinten is jelentkezik a szenpaikóhai-viszony: a céghez korábban belépett munkatárs ugyanis a hierarchia magasabb fokán helyezkedik el.

Érthető tehát, hogy miért tartják fontosnak, hogy már kisiskolás korukban neveljék és erősítsék a gyerekben a csapatszellem fontosságát, a szociális készségek fejlesztését, az osztályon belüli, illetve a más évfolyamra járókkal való közös tevékenységekben való részvételt. Tanulmányomban azt vizsgálom, hogyan nevelik a gyerekeket már kisiskolás koruktól a közösségi életre, milyen készségek erősítésére fókuszál a nemzet tanterv, hogyan segíti mindezt az iskolai közös takarítás. Kutatások kiemelik, hogy milyen nagy hangsúlyt kap Japánban az iskolai nevelésben a közösségi készségek fejlesztése (Le Tendre, 1999; Tsuneyoshi, 1994). A pedagógusok a nevelés során nagy jelentőséget tulajdonítanak a csapatban való munkának, a közös konfliktuskezelésnek (Le Tendre, 1999. 291. o.). Olyan aktivitásokat szerveznek, ahol a gyerekek csoportokban dolgoznak együtt (takarítás, ebéd felszolgálása, stb.). A gyerekek sokszor vezető szerepet kapnak, elemzik a helyzetet, jelentéseket tesznek, és csoportként döntéseket kell hozniuk, a pedagógus pedig sokszor a háttérben marad.

\section{A takarítás megítélése az egyes kultúrkörökben}

Okihara (1978) szerint a világ országait három csoportra lehet osztani aszerint, hogyan tekintenek a takarításra. Véleménye szerint a görög-római kulturális háttérrel rendelkező társadalmakban a takarítást alantas munkának tekintették, amelyet általában cselédek végeznek. Ide tartoznak a nyugat-európai, közép-kelet-európai országok, Amerika, DélAfrika, Észak-Afrika, Új-Zéland, Ausztrália. Ezekben az országokban takarító személyzetet alkalmaznak az iskolákban, és nem a gyerekekkel végeztetik az alantasabbnak számító fizikai munkát. A második csoportba 
a Szovjetunió, Kelet-Európa egyes országait és Kubát sorolja, ahol takarító személyzetet alkalmaznak, de a tanulók is besegítenek a takarításba. A harmadik csoportban a buddhista hagyományokkal rendelkező országokat említi, ahol a tanulók takarítják az iskolát. A zen templomokban ugyanis a folyosók takarítása egyet jelent rendet rakni az emberi testben és elmében (Okihara, 1978. 37-38. o.).

A japán gyerekek már Meidzsi kor (18681912) óta maguk végzik a takarítást az iskolákban, és nemzetközi szemszögből nézve, az iskolai takarítás a japán oktatási rendszer egyik sajátosságának számít (Okihara, 1978). De már jóval korábban, a középkorban, a buddhista templomokban is maguk takarítottak a tanulók, és később, az Edo-korban (1603-1867) az ún. terakojákban is ez volt a szokás (Okohara, 1978. 33.o.). Japánban úgy vélik, hogy a közös takarítás a szolidaritást és a közösségérzést erősíti. A takarítás elvégzése után a kis csoportok összeülnek, és átbeszélik, hogyan értékelik az aznapi munkát ( $L e$ Tendre, 1999. 302. o.).

\section{A japán nemzeti alaptanterv}

A japán iskolai oktatás háromfokozatú: az első hat év az általános iskola (sógakkó), ezt követi a három éves alsó-középiskola (csúgakkó), majd a szintén három éves felső-középiskola (kótógakkó). Tanulmányomban a legmeghatározóbb első hat évre, az általános iskolai évekre fókuszálok. Japánban az általános iskolai oktatás kötelező és ingyenes, az oktatás 99\%-ban állami intézményekbe zajlik.

A japán nemzeti alaptanterv az általános iskolai tevékenységeket akadémiai és nem akadémiai területekre bontja. Az akadémiai tevékenységekhez sorolandók az egyes tantárgyak: az anyanyelv (amelynek a bonyolult írásrendszer miatt kiemelt jelentősége van), társadalom, számtan, természettudomány, életvitel, zene, rajz és technika, háztartás, testnevelés, idegennyelv. Ezen kívül speciális tantárgyként megjelenik az erkölcstan. Ugyanakkora hangsúlyt fektetnek a nem akadémiai területekre is, a speciális, nem tanórai tevékenységeknek a szociális készsé- gek fejlesztésében jut nagyon fontos szerep (Tsuneyoshi, 1994). Természetesen minden oktatási rendszer az egész embert kívánja fejleszteni, Japánban azonban ez a gyakorlatban is megvalósul (Fülöp, 1998; Tsuneyoshi, 1994). Japánban ugyanis az akadémia ismeretek mellett a szociális készségek ismerete ugyanolyan fontossággal bír. Különösen az általános iskolában nagy hangsúlyt fektetnek a kiscsoportos foglalkozásokra, ahol nagy szerepe van a csoporton belüli együttműködésnek (Tsuneyoshi, 1994).

Japánnak az 1950-es évektől van nemzeti alaptanterve, amelyet tíz évenként felülvizsgálnak (Sugai, 2007. 44. o.). Előadásomhoz az Oktatásügyi Minisztérium (MEXT-Ministry of Education, Culture, Sport, Science and Technology) által 2017 márciusában kiadott általános iskolai nemzeti tantervet, az úgynevezett gakusú sidó jórjó-t használtam. Az új, átdolgozott tanterv 2020 áprilisában lép érvénybe, és a 2008-as - jelenleg hatályos kiadás - átdolgozott változata. Az általános iskolai tanterv a következőképpen épül fel: 1 . fejezet. Szószoku (Általános rendelkezések/ szabályok), 2. fejezet. Kaku kjóka (Az egyes tantárgyak), 3. fejezet. Tokubecu no kjóka. Dótoku (Speciális tantárgy. Erkölcstan), 4. fejezet. Gaikokugo kacudó (Idegennyelvi tevékenységek), 5. fejezet. Szógóteki na gakusú no dzsikan (Integrált tanulás), 6. fejezet. Tokubecu kacudó (Speciális tevékenységek).

A 2. fejezet az egyes tantárgyakat tárgyalja, és külön alfejezetekben ismerteti az egyes müveltségi területekre vonatkozó célkitűzéseket.

Jelen kutatás szempontjából a Speciális tevékenységek c. fejezet bír jelentőséggel.

A speciális tevékenységek általános célja a gyerekek mint a csoport és társadalom formálói szemléletének és gondolkodásmódjának alakítása különböző tevékenységeken való aktív részvétellel. A csoporttevékenységekkel a következő készségek fejlesztését célozzák meg:

1. Másokkal együttmüködve megtanulni a csoporttevékenységek jelentőségét, valamint megérteni a csoporttevékenységekben való részvételhez szükséges és elengedhetetlen dolgokat. 
2. Észrevenni az egyéni és közösségi életben, valamint az emberi kapcsolatokban felmerülő problémákat, és megoldást találni rájuk megbeszéléssel és konszenzusra törekvéssel, majd a megtanulni megfelelö döntést meghozni.

3. A csoporttevékenységek során elsajátítottakon keresztül olyan viselkedésre nevelni a gyermekeket, hogy a csoport és a társadalmon belüli emberi kapcsolatokat jobban alakítsák, jobban elmélyítsék az egyéni életmódról való gondolkodást, és az önmegvalósításon dolgozzanak1 (saját fordítás).

(Gakusú sidó jórjó, 2017. 164. o.)

A speciális tevékenységek között a következőket nevezi meg a nemzeti tanterv:

1. Gakjú kacudó (osztálytevékenységek),

2. Dzsidókai kacudó (gyerektanács),

3. Kurabu kacudó (szakkörök/klubtevékenységek),

4. Gakkó gjódzsi (iskolai rendezvények).

Az osztálytevékenységek célja különböző problémák, feladatok megoldása konszenzusra való törekvéssel, együttműködve a többi osztálytárssal. A tanterv kiemeli a feladatmegosztás, feladatkörök tudatosításának fontosságát, valamint a csoporton belüli harmonikus együttműködést is. Egyik fontos célként nevezik meg a hétköznapi életre, az egészségbiztonságra való nevelés fogalmát is. Itt jelenik meg külön alpontként a helyes táplálkozási szokások kialakítása. Az iskolai ebédidőt használjuk arra, hogy kialakítsuk az egészséges táplálkozást a gyerekekben, ugyanakkor a közös evés az emberi kapcsolatok javítását is szolgálja.

\section{1 (1) 多様な他者と協働する様々な集団活動の意義} や活動を行う上で必要となる

ことについて理解し，行動の仕方を身に付けるようにする。

（2）集団や自己の生活，人間関係の課題を見いだし，解決 するために話し合い，

合意形成を図ったり，意思決定したりすることができるよ うにする。

（3）自主的，実践的な集団活動を通して身に付けたことを 生かして，集団や社

会における生活及び人間関係をよりよく形成するととも に，自己の生き方に

ついての考えを深め, 自己実現を図ろうとする態度を養う。
Az iskolai közös takarítással a társadalmi tevékenységekben való részvételt, az elkötelezettséget kívánják erősíteni. Kiemelik az ügyeletben végzett tevékenység és a felelősség fontosságát, a saját feladatkör létének tudatosítását (Gakusú sidó jórjó, 2017. 164. o.). Érdekes kiemelni, hogy a nemzeti alaptanterv ugyan nem rendelkezik arról, hogy napi 1520 percet takarításra kellene fordítani, mégis minden iskolában így történik.

Másik fontos alappillér a szakkörökre vonatkozó irányelvek. Itt az egyik legfontosabb tényező a más évfolyamra járó tanulókkal való együttmüködés, ugyanis ezáltal sajátítják el a szenpai-kóhai kapcsolatrendszer müködését. A gyerekek részt vesznek a szakkörök vezetésében és a programok összeállításában, megtervezésében. Az eredményeiket pedig bemutató formájában elő is adják a szűkebb környezetükben (Gakusú sidó jórjó, 2017. 167. o.).

Az iskolai rendezvények között említik a különböző ceremóniákat, kulturális és sporttevékenységeket, kirándulásokat, stb, ezzel készítve fel a gyerekeket a helyi rendezvények, eseményeken való részvételre (Gakusú sidó jórjó, 2017. 167. o.).

A 160 oldalas tanterv mellé segédmelléklet is tartozik, a Sógakkó sidórjórjó kaisecu, amely a tanterv interpretálásában hivatott segítséget nyújtani. A Speciális tevékenységek alfejezethez tartozó segédlet 163 oldal terjedelmü, és részletesebben fejti ki a tanterv célkitűzéseit, a tevékenységek tartalmát. Kifejti, hogy a Speciális tevékenységek egyik fö célkitűzése a gyerekek társadalmi beilleszkedésének elősegítése. A család után az osztály és az iskola az a társadalmi csoport, amelybe a gyerekek bekerülnek. Így a különböző iskolai tevékenységeken keresztül tanulják meg a kapcsolatépítés menetét, illetve saját egyéni hozzájárulásukkal segítik a csoport fejlődését. Mindezeket a képességeket pedig később, a társadalom felnőtt tagjaiként a munkahelyen és környezetükben kamatoztathatják (Gakusú sidó jórjó. Kaiszecu, 14. o.).

Az osztály az a társadalmi csoport, amelyhez a kisiskolás a család mellett tartozik. Az osztályon belüli tevékenységeken keresztül 
Miért is a gyermekek takarítanak a japán iskolákban?

olyan dolgokat sajátítanak el a gyerekek, amelyeket később a családi életben vagy a munkahelyi mindennapokban tudnak kamatoztatni. A gyerekek eltérő gondolkodásmóddal és érzésvilággal bíró társakkal találkozhatnak, és megtapasztalják a konfliktushelyzeteket és az ellenségeskedést.

A gyerektanács autonóm csoportnak számít, az itt elsajátítottaknak felnőttként az egyes közösségekben való aktivitásuk során vehetik majd hasznát. A különböző bizottságokban (környezetvédelmi bizottság, könyvtári bizottság stb.) való részvétellel felsőbb évesekkel is együtt dolgoznak, és ezáltal megint olyan készségeket fejlesztenek, amelyek a hierarchikus felnőtt társadalomban hasznukra válik.

A szakkörök hasonló érdeklődésű, eltérő évfolyamra járó gyerekeket tömörítenek. A szakkörökön elsajátított készségek később, a felnőtt társadalomban hasonlóképpen a klubokban, társaságokban hasznosíthatók. A szakköri tevékenységek szerepéröl Gordon Győri János részletesen ír tanulmányában (1998).

Az iskolai rendezvények egy nagyobb csoport, az iskola éves eseményeit jelenti. Az itt megélt élményekkel a csoporthoz való tartozás élményét, a szolidaritást kívánják erősíteni. Ez később, a felnőtt társadalomban a nagyobb helyi rendezvényeken való részvételre készíti fel a gyerekeket (Gordon Györi, 1998. 20-21. о.).

\section{Az iskolai takarításra szakosodott külsős cégek, tanári kézikönyvek}

A nemzeti alaptanterv tehát a célokat, fejlesztendő kompetenciákat fogalmazza meg, de pontos útmutatást nem ad az iskolai takarításhoz. Ezért a nagy terjedelmű nemzeti tanterv mellett tanári kézikönyvek segítik a pedagógusokat a nem akadémiai jellegü tevékenységek megszervezésében és lebonyolításában. A Duskin nevü cég 2000 óta segíti a pedagógusok munkáját. Arra vállalkoztak, hogy elkészítik a takarításra vonatkozó tanmenetet. Az általános iskolai tanmenet a következőkre fókuszál: 1. A takarítás alapjainak elsajátítása és alkalmazása, 2. Elemzőkészség kialakítása a minél jobb minőségi takarításért, 3, A takarítási ismeretek összekapcsolása és fejlesztése. A cég kihelyezett oktatást is tart a kisiskolásoknak, ahol hét 45 perces órán a következőket oktatják: 1. Vajon miért is takarítunk?, 2. A takarító eszközök helyes használati módja, 3. Az iskolai takarítás menete, 4. Takarítsunk a közvetlen környezetünkben, 5. Az egyes szennyeződések takarítási módja, 6. A takarítás „átmeneti követelményeinek” kidolgozása, 7. A különböző takarítási módok a mindennapokban (Duskin, 2011). A takarítás előkészítéséről egy külsős cég által szerkesztett könyv gondoskodik. A JBMA (Japan Building Maintanence Ass.) által összeállított anyag bemutatja a takarításhoz használt eszközöket (seprü, partvis, lapát stb.), ismerteti a különböző szeméttípusokat is (nagyobb hulladékok, ételmaradékok, olajfoltok, grafittik stb.), a takarításhoz használt tisztítószereket, stb. Majd illusztrációk segítségével bemutatja az egyes takarítóeszközök helyes használatát, rendeltetését. Ezek után lépésről lépésre ismerteti az egyes munkafolyamatokat. A könyv végén a takarítást követő alapos kézmosás menetét ismerteti a könyv. A tanulóknak szóló kézikönyv közérthetőbb módon, viccesebb képekkel ismerteti ugyanezt (Kidsbma).

\section{Takarítás az iskolában}

Ebben az alfejezetben azt kívánom bemutatni, hogyan valósul meg a gyakorlatban az iskolai takarítás. Az általános iskolai órarend nagyságrendileg minden iskolában az alábbiak szerint alakul:

$$
\begin{aligned}
& \text { 8:20-8:30: reggeli gyűlés } \\
& \text { 8:45-12:20: az első négy tanóra } \\
& \text { 12:20-13:05: ebédidő } \\
& \text { 13:30-13:45: takarítás } \\
& \text { 13:50-14:35: 5. óra }
\end{aligned}
$$

Ezek után kezdődnek a délutáni foglalkozások, szakkörök.

Néhány perc eltéréssel minden iskolában a fentiek szerint zajlik a kisiskolások egy napja. Az órarendből kiolvasható, hogy mekkora szerepet tulajdonítanak a közös ebédelésnek 
és a takarításra szánt időnek. Az ebédelésre nagyságrendileg 45 percet szánnak. Az ebédet a szolgálatos tanulók szolgálják fel, illetve ők is szedik össze utána az edényeket. Ebéd után 20 perc szünet következik. Ezután kerül sor a 15-20 perces takarításra. Ez azt jelenti, hogy a takarítással töltött idő napi 15 perc, éves szinten 60 órát tesz ki, azaz megegyezik az egyes tantárgyak éves óraszámával. A tanulók kis csoportokba (úgynevezett hanokba) szerveződve végzik a munkát. Iskolánként változhat, de létezik az ún. tatevari han rendszer is, amikor felső és alsó évfolyamos hallgatókból álló csoportokban végzik a munkát. Így a nagyobb gyerekek segítik és felülvizsgálják a kisebbek munkáját. A tanulók maguk takarítják nem csak saját osztálytermüket, de a folyosók, mellékhelyiségek, az udvar rendben tartása is az ő feladatuk.

A takarítási munka rotációban zajlik, minden nap más helyiségben takarítanak az egyes csoportok, akik ma a táblát törlik, holnap a padokat mossák, majd a folyósokat és így tovább. A munka végeztével a hallgatók reflektálnak saját és mások munkájára, értékelik, és jelentést tesznek. A pedagógus is részt vesz a munkában, leginkább segítő szerepet tölt be, nem jellemző, hogy a pedagógus irányítaná a munkát. Jellemzően a felelős tanulók adják az utasításokat és szintén ők értékelik a munkát (Tsuneyoshi, 1994). Természetesen Japánban is előfordul, hogy valamelyik tanuló szabotálja a munkát, vagy nem megfelelő minőségü munkát végez. Mivel azonban a célok, szerepek mindenki által világosak, a munka menete pedig mindenki által ismert, és rutinszerüen végzik a munkát, jobban tudnak egymásra figyelni. És mivel kiscsoportokban dolgoznak, mindenki érdeke az együttmüködés, ezért biztatiák is egymást a munkára (Tsuneyoshi, 1994). A csoportos értékelésnél nyilván reflektálnak is a problémákra a csoportfelelösök, az iskolai takarításnak azonban a lényege nem a makulátlan tisztaságra való törekvés, hanem a tantervben megfogalmazott készségekre való nevelés. A munka pontos forgatókönyv szerint halad, a szellőztetéstől kezdve minden egyes mozzanatot tartalmaz az útmutató.

\section{Pedagógusok és tanulók véleménye}

A Duskin cég 2001 óta minden évben rendszeresen országos felmérést végez interneten a tanulók és a pedagógusok körében a takarítás témakörében. Honlapjukon a 2011es felmérés eredményei olvashatók. (Duskin, 2011). A felmérésből kiderül, hogy a gyermekek jónak ítélik meg az iskola, osztálytermük, valamint a mellékhelyiségek tisztaságát. Az általános iskolások 76.7\%-a válaszolta, hogy a saját kis csoportjukon belül a takarítási feladatok meg vannak határozva. Továbbá a válaszadók $81.8 \%$ a szerint a takarítási mód és a sorrend is eleve adott. A válaszadók 79\%a hetente legalább öt alkalommal takarít. A takarítási munkálatok közül a söprögetés a legnépszerűbb, a tanulók 55.7\%-a választotta, majd ezt követi a táblatörlés, 38.8\%-kal. A megkérdezett pedagógusok szerint a leggyakrabban használt takarítóeszköz a felmosórongy (98.5\%) és a szemétlapát (92.2\%), de negyedik helyen megjelenik a WC-kefe is (77\%). Arra a kérdésre, hogy együtt takarít-e a gyerekekkel a pedagógus is, a válaszadók 49\%-a válaszolta azt, hogy minden alkalommal együtt takarít a gyerekekkel. Arra a kérdésre, hogy mit tanított nekik a pedagógus a takarítással kapcsolatban, a válaszadó általános iskolások több, mint 30\%-a azt válaszolta, hogy a takarítás jelentőségét és fontosságát, 47.4\%-uk pedig a takarítási sorrendet említette. Arra a kérdésre, hogy szeretnek-e takarítani 66\% válaszolta azt, hogy nem is szeret, de nem is utálja.16\%-uk mondta, hogy szeret, $18 \%$ pedig, hogy nem szeret takarítani. A pedagógusok arra a kérdésre, hogy hol tanultak takarítani, 70.3\%-uk az iskolát jelölte meg.

Fontos megjegyezni, hogy míg a gyerekek az iskolában panasz nélkül elvégzik a rájuk szabott feladatokat, otthon már kevésbé lelkeses vagy egyáltalán nem veszik ki részüket a házimunkából.

\section{Konklúzió}

Tanulmányomban bemutattam, hogyan zajlik a japán iskolákban a takarítás, illetve, hogy hogyan jelenik meg a takarítás a nemzeti 
Miért is a gyermekek takarítanak a japán iskolákban?

alaptantervben, valamint, hogyan segítik külsős cégek a pedagógusok és tanulók takarítási tevékenységre való felkészítését. Arra tettem kísérletet, hogy bemutassam, mire is jó, ha a gyerekek takarítanak maguk után az iskolában, honnan ered mindez, hogyan készítik fel rá a tanulókat, és mi a célja ezeknek a tevékenységeknek. Megválaszolandó kérdés marad, hogy hazánkban meghonosítható-e egy hasonló iskolai kultúra, elfogadnák-e a szülők, pedagógusok, gyerekek. Egy biztos, ha a gyerekeknek kell feltakarítaniuk maguk után, jobban odafigyelnek a tisztaságra.

\section{Felhasznált irodalom}

Chie, N. (1970): Japanese Society. University of California Press, Berkely and Los Angeles.

Fülöp Márta (1998): A csoport és közösség szerepe a Japán társadalomban. Pszichológia, 18. 4. sz., 469-498.

Gordon Győri János (1998): Mitől hatékony még a japán oktatás? Magyar pedagógia, 98. 4. sz., 273-317.

Hidasi Judit (1998): Szavak. Jelek. Szokások. Windsor Kiadó, Budapest.

Hofstede, G. (1980): Culture's Consequences: International Differences on Work-Related Values. Sage Publications, Beverly Hills.

Hidasi Judit (2004): Interkulturális kommunikáció. Scolar Kiadó, Budapest.

Laczkó Zsuzsa és Radnai Tamás (1993): Paprikáskrumpli evöpálcikával. Levelek Japánból. Babits Kiadó, Szekszárd.

Le Tendre, G. K. (1999): Comminity-Building Activities in Japanese Schools: Alternative Paradigms of The Alternative School. Comparative Education Review. 43. 3. sz., 283-310.

Németh Gáborné Doktor Andrea (2008): A szociális kompetencia fejlesztésének lehetőségei az iskolában. Pedagógia folyóiratok, 1. URL: http://folyoiratok.ofi.hu/uj-pedagogiais z e m le / a - s z o cialis - kom petencia fejlesztesenek-lehetosegei-az-iskolaban

Okihara, Y. (1978): Pupil Participation in School Cleaning: A Comparative Survey. Comparative Education. 14. 1. sz., 33-40. https://doi.org/10.1080/0305006780140104

Székács Anna és Hernádi András (2003): A japán gazdaság, társadalom és koomunikáció átalakulása az ezredfordulón. Budapesti Gazdasági
Főiskola Külkereskedelmi Főiskolai Kar, Budapest.

Sugai, T. (2007): A Public Elementary School As A Cultural Context: Japanese Children Learning to Perceive Their Environment. Thesis for MA in Applied Anthroplogy. Oregon State Univ.

Tsuneyoshi, R. (1994): Small Groups in Japanese Elementary Classrooms: Camparison with The United States. Comparative Education, 30. 2. sz., 115-129. https://doi.org/10.1080/0305006940300204

Hofstede, G.. The 6-D Model of National Culture. URL: https://geert-hofstede.com/japan.html (utoljára megtekintve: 2017.10.11.)

Nemzeti alaptanterv általános iskolák számára. (2017-es kiadás)

URL: http://www.mext.go.jp/component/a_ menu/education/micro_detail/__icsFiles/afie ldfile/2017/05/12/1384661_4_2.pdf (utoljára megtekintve: 2017.10.11.)

Nemzeti alaptanterv (magyarázat) általános iskolák számára. (2017-es kiadás)

URLhttp://www.mext.go.jp/a_menu/shotou/ new-cs/1387014.htm (utoljára megtekintve: 2017.10.11.)

Duskin Rt.: Kjóin kara mita gakkószódzsi ni kanszuru dzsittai csósza (Pedagógus szemmel az iskolai takarításról. Tényfelmérés).

URL: http://www.duskin.co.jp/torikumi/ gakko/curriculum/soujikyouiku/index.html

https://www.duskin.co.jp/torikumi/gakko/ research/pdf/research2011_02.pdf (utoljára megtekintve: 2017.10.11.)

Pápai-Vonderviszt Anna: A japán iskolai élményeim, avagy mit lenne érdemes átvennünk a japán oktatási rendszerből?

URL: https://sudy.co.hu/a-japan-iskolaielmenyeim-avagy-mit-lenne-erdemesatvennunk-a-japan-oktatasi-rendszerbol/ (utoljára megtekintve: 2017.10.11.)

Japan Building Maintenance Association. URL: http://www.kids-bma.jp/manual/ (utoljára megtekintve: 2017.10.11.)

\section{Forrás:}

Nacume Szószeki (2003): A kölyök. (Vihar Judit ford.). Balassi Kiadó, Budapest. 


\section{Why do pupil clean the classroom in Japan?}

This research was inspired by the fact that there are some school activities in Japan, which are considered by those who had the opportunity to live longer in Japan as good examples to be followed. Such school activities are cleaning, serving food, etc. This paper lays focus upon an education system that puts the same emphasis on non-academic and academic school activities. The paper shows how is cleaning regarded in different cultures, gives a short description of the Japanese national core curriculum, and gives examples on the process of cleaning in Japanese elementary schools.

Keywords: Japan, Japanese educational system, japanese national core curriculum, uchi-soto, senpai-kohai

Somodi Júlia (2019): Miért is a gyermekek takarítanak a japán iskolákban?. Gyermeknevelés, 7. 1. sz., 61-68. 